\title{
Incidence of Personal Care Products in Surface Water of Middle Tennessee Urban and Rural Sub-Watersheds
}

\author{
Ravneet Kaur, Anonya Akuley-Amenyenu, Qi Deng, Sam O. Dennis* \\ Department of Agricultural and Environmental Sciences, Tennessee State University, Nashville, TN, USA \\ Email: *sdennis@tnstate.edu
}

How to cite this paper: Kaur, R., Akuley-Amenyenu, A., Deng, Q. and Dennis, S.O. (2018) Incidence of Personal Care Products in Surface Water of Middle Tennessee Urban and Rural Sub-Watersheds. Journal of Water Resource and Protection, 10, 507-521.

https://doi.org/10.4236/jwarp.2018.105027

Received: February 15, 2018

Accepted: May 27, 2018

Published: May 30, 2018

Copyright $\odot 2018$ by authors and Scientific Research Publishing Inc. This work is licensed under the Creative Commons Attribution International License (CC BY 4.0).

http://creativecommons.org/licenses/by/4.0/

(c) (i) Open Access

\begin{abstract}
Personal care products (PCPs) are stable and are recognized as important chemicals of emerging concern in freshwater resources in the United States (US), including surface water. Although little is known about the bio accessibility or biodegradation of these chemicals in the environment. Their primary source of entry into water bodies includes activities such as bathing and showering as well as improper disposal of unused personal care products. We conducted a study to monitor the incidence of personal care products in two rivers (surface water) in Middle Tennessee. The objectives were to determine the incidence of personal care products in surface water of urban and rural sub-watersheds. Secondly, to identify the most frequently detected PCPs in the rivers monitored in the sub-watershed. Water samples were collected from the Cumberland River and Collins River. These rivers represented surface water drained by urban and rural watersheds respectively in Middle Tennessee. The surface water samples were analyzed for the presence of personal care products using GC-MS. During sampling, water quality parameters of interest were collected in-situ with a multi-parameter data-sonde. Low-level concentration of compounds containing PCPs was detected in the two rivers monitored. Personal care products detected included the active ingredients in perfumes (Docosane, Heptadecane, Methyl hexadecanoate, and Undecane), antiperspirants (Octadecanol, and Pentadecalactone), skin conditioners (Cyclotrisiloxane, Isohexyl palmitate, Methyl palmitate, and CedroI), and shampoos (1-Hexadecanol, Hexadecanoic acid, and Nonanal).
\end{abstract}

\section{Keywords}

Personal Care Products, Cumberland River, Collins River, Surface Water, Water Quality 


\section{Introduction}

Personal care products are chemicals marketed for direct use by consumers on the human body. While these chemicals exclude over the counter drugs, a majority of the chemicals have active ingredients or preservatives associated with cosmetics or fragrances. In general, some of these chemicals are directed at altering odor, appearance, touch or taste and with no significant biochemical activity. Almost no attention was given to personal care products in the past as far as effects from intended use on human health. Hence, substantial quantities have been used more than recommended. There has been a significant increase in demand for personal care products due to population growth and as well enhancing the quality of life, which in turn has increased the production of these chemicals [1] [2]. PCPs have been released into the environment in significant quantities via different sources that have included but not limited to recreational and human activities. Consequently, these chemicals have been detected in aquatic environment including rivers, lakes, groundwater; and tissues of some organisms (crustacean, fish, mussels, and mollusks) [2]-[8]. However, in recent years, the active ingredients of these personal care products have come under intense scrutiny by the Food and Drug Administration (FDA) and Environmental Protection Agency (EPA) due to the environmental and human health concerns [9].

Personal care products can be directly released into waters or volatilized into the air (e.g., musks). In addition, activities like washing hands, bathing, and showering also contribute towards this process [9]. The detection of PCPs in the landscape is a continuing threat to the environment partly due to their persistent nature in the environment, because they can persist for months to years [10]. Due to their moderate to high lipophilic nature, these chemical compounds have the potential to accumulate in the environment. However, little is known about the potential health effects to humans or aquatic organisms exposed to the trace levels of these chemicals when present in surface water [2] [3] [11] [12] [13].

While this study was based on a watershed scale approach, the rivers selected are located in urban and rural sub-watersheds. The objectives of the study are as delineated below:

1) To determine the incidence of personal care products in surface water of an urban and rural sub-watershed in Middle Tennessee.

2) To identify the most frequently detected personal care products in the surface water monitored.

It is hypothesized that: 1) the presence of PCPs in surface water contributes to the impairment of surface water quality; 2) the incidence of personal care products in the streams will fluctuate as a function of the seasons.

\section{Materials and Methods}

\subsection{Study Sites}

Davidson and Warren counties from Middle Tennessee were chosen for this 
study. These counties were selected because: 1) they represent urban and rural watersheds in Middle Tennessee; 2) the watersheds proximity to the main campus of the university. The watershed and associated rivers are: Cumberland River watershed (located in Davidson County), and Collins River watershed (located in Warren County).

\subsubsection{Cumberland River}

Cumberland River (Figure 1) is a major waterway of southern United States. The watershed has a drainage area of 921 square miles. It flows east to west through the middle of Davidson County. According to 2010 census, Davidson County is the second most populated county in Middle Tennessee, with a population of 626,681. Although Cumberland River is predominantly rural, it also spans some large cities including Nashville and Clarksville in Middle Tennessee. Land use in Davidson County is mainly industrial and residential. The portion of Cumberland River in the study is in the Middle Cumberland River sub watershed located in Nashville, TN.

\subsubsection{Collins River}

The Collins River (Figure 2) is a 67-mile long stream in an east-central portion

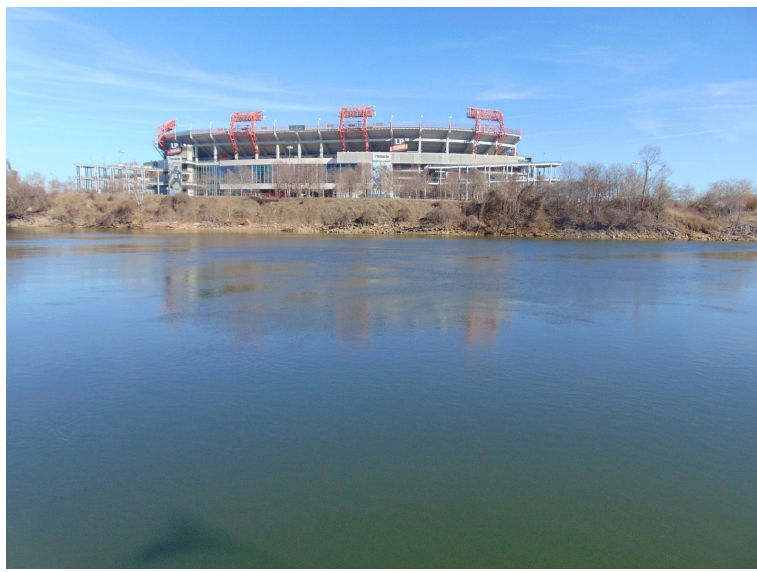

Figure 1. Sampling site for Cumberland River, Nashville TN. (36 $\left.09^{\prime} 47^{\prime \prime N} 86^{\circ} 46^{\prime} 28^{\prime \prime} \mathrm{W}\right)$.

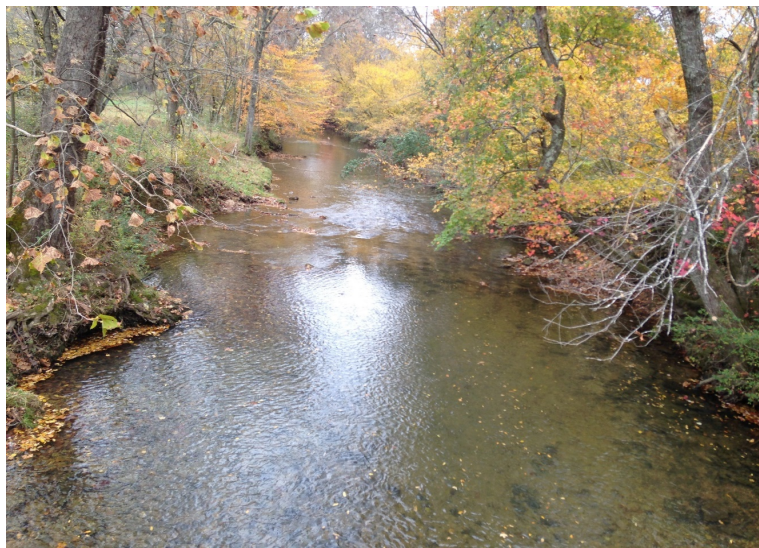

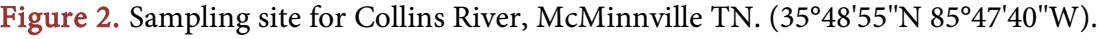


of Middle Tennessee. Collins River watershed covers 811 square miles and drains Warren, Grundy, Van Buran, Sequatchie, Coffee, and Cannon counties. Over half of the watershed is forested, and about one third is used for pasture, row crops, and nursery crops. Land use in Warren County is primarily agricultural, with a large portion being nursery crop production.

\subsection{Analytical Methods}

Sampling of PCPs and physicochemical water quality parameters was conducted for three seasons for two years: summer (2014), fall (2014), winter (2015), summer (2015), fall (2015) and winter (2016). Water sampling started during the summer of 2014. During each season, water samples were collected weekly for five consecutive weeks. Grab samples were collected during base flow (normal flow conditions) and in some instances after rainstorm events. A Teflon bailer was used to collect the water samples, as shown in Figure 3. Teflon bailers have no interference with chemicals that are being detected in the study. Moreover, it allows sampler to retrieve water sample from a safe distance. Duplicate samples were collected for the PCPs analysis and at the same time samples were collected for physico-chemical analysis.

In-situ monitoring was conducted for water quality parameters of interest which included temperature, $\mathrm{pH}$, dissolved oxygen, and turbidity. Measurements were taken with Eureka Manta2 ${ }^{\mathrm{TM}}$ sonde or data loggers (Eureka Water Probes, Austin TX). The data logger was interfaced with the applicable sensors, as shown in Figure 4, and deployed in the streams to at least a $45 \mathrm{~cm}$ depth for

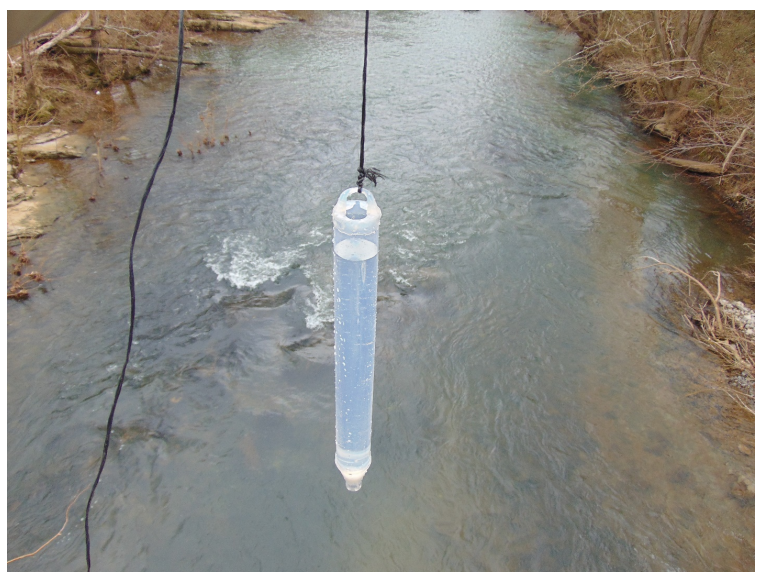

Figure 3. Teflon bailer used for water sample collection.

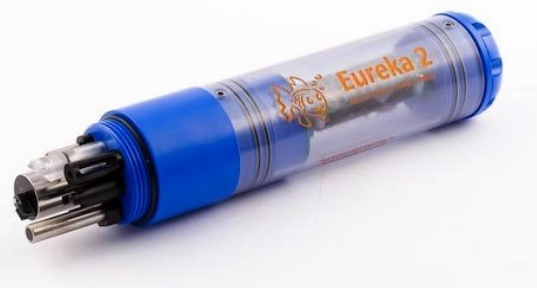

Figure 4. Data logger: Eureka Manta2TM used for in situ monitoring. 
about 3 minutes. Prior to deployment, the Manta data logger was calibrated according to instrument specifications. A minimum of two readings were taken in situ, and their average was used for further analysis.

\subsection{Analysis of Water Samples for the Presence of PCPs}

Personal care products used by consumers are often washed down the drains, with a pathway to wastewater treatment plants. At the treatment plants they can bind to particles in sludge or discharged into local water where they eventually bind to sediments in the water.

The problems associated with sample analysis due to co-extracted compounds are collectively termed "matrix effects". Hence in order to achieve a successful analysis, the amount of co-extracted natural organic matter was extremely minimized in the extraction protocol. Solid-Phase Extraction (SPE) was used to separate compounds in the sample based on their polarities and solubilities in specific solvents used for extraction. The samples were fed into the GC-MS (HP 6890 series GC System; Hewlett-Packard) where the gas chromatography separated the organic compounds, and the mass spectrometer identified the separated compounds (Figure 5).

\section{Results and Discussion}

The results consist of a two-year (2014-2016) monitoring data of Personal Care Products (PCPs) in two rivers as well as relevant water quality parameters of interest. The results of the data presented reflect the findings in the two rivers (Cumberland River and Collins River) monitored. 1) Personal care products detected in Cumberland River during Summer 2014, Fall 2014, Winter 2015, Summer 2015, Fall 2015, and Winter of 2016; 2) Personal care products detected in Collins River during Summer 2014, Fall 2014, Winter 2015, Summer 2015, Fall 2015, and Winter of 2016. The results of pertinent water quality parameters determined in each river per season are also depicted herein. These water quality parameters are temperature, $\mathrm{pH}$, dissolved oxygen, and turbidity.

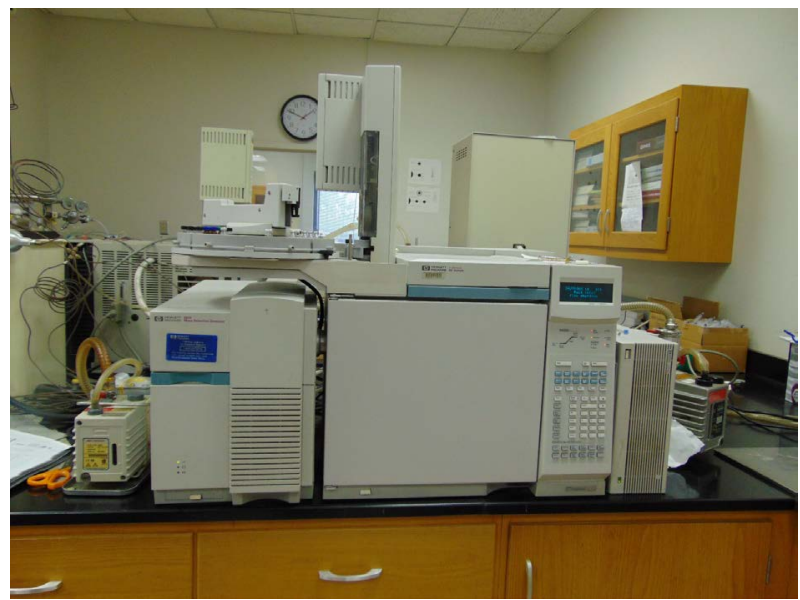

Figure 5. GC-MS used for the PCPs analysis of water samples. 
Cumberland River data: Personal care products detected in Cumberland River during 2014-16 are presented in Table 1. The PCPs detected during summer of 2014 and 2015 included 1-Chlorodecane, an anti-microbial agent; 1-Hexadecanol, an opacifier in shampoos and emollient in skin creams; 9-Octadecenoic acid, a moisturizer and Disiloxane, an emollient in skin conditioners. Among these chemicals were several fragrance agents that include but not limited to Docosane, Dodecane, Heneicosane, Heptadecane, and Hexadecane. Additionally, Methyl Palmitate, commonly used as an intensive skin care lotion; Octadecan-1-ol, an antiperspirant compound and Octadecane, another

Table 1. Personal Care Products, $\mathrm{n}=2$; Cumberland River: Summer 2014, Fall 2014, Winter 2015, Summer 2015, Fall 2015 and Winter 2016

\begin{tabular}{|c|c|c|c|c|c|c|c|c|}
\hline \multirow{2}{*}{$\#$} & \multirow{2}{*}{ Chemical Name } & \multirow{2}{*}{$\begin{array}{c}\text { CAS } \\
\text { Number }\end{array}$} & \multicolumn{2}{|c|}{ Summer } & \multicolumn{2}{|c|}{ Fall } & \multicolumn{2}{|c|}{ Winter } \\
\hline & & & 2014 & 2015 & 2014 & 2015 & 2015 & 2016 \\
\hline 1. & 1-Chlorodecane & $1002-69-3$ & & & & & & $\Phi$ \\
\hline 2. & 1-Hexadecanol & $36653-82-4$ & $\#$ & & & & & $\Phi$ \\
\hline 3. & 2,6-dimethyloctan-2-ol & $18479-57-7$ & & & & & & $\Phi$ \\
\hline 4. & 3-Hexanol & $623-37-0$ & & & & $\wp$ & & \\
\hline 5. & 9-Octadecenoic acid & $111-62-6$ & $\#$ & & & & & \\
\hline 6. & Cyclotrisiloxane & $541-05-9$ & & & & & $\mathrm{X}$ & $\Phi$ \\
\hline 7. & Disiloxane & $107-46-0$ & $\#$ & & $\ddagger$ & & $\mathrm{X}$ & \\
\hline 8. & Docosane & $211-121-5$ & $\#$ & & $\ddagger$ & & & \\
\hline 9. & Dodecane & $112-40-3$ & $\#$ & & & & & \\
\hline 10. & Heneicosane & $629-94-7$ & $\#$ & & $\ddagger$ & & $\mathbf{X}$ & \\
\hline 11. & Heptadecane & $629-78-7$ & $\#$ & $\beta$ & $\ddagger$ & 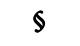 & & $\Phi$ \\
\hline 12. & Hexadecane & $544-76-3$ & $\#$ & $\beta$ & $\ddagger$ & $\S$ & & $\Phi$ \\
\hline 13. & Hexyl butanoate & $2639-63-6$ & & & & $\$$ & & \\
\hline 14. & Isohexyl palmitate & $55194-91-7$ & & & & & $\mathbf{X}$ & \\
\hline 15. & Methyl heptanoate & $106-73-0$ & & & & & & $\Phi$ \\
\hline 16. & Methyl Palmitate & $112-39-0$ & $\#$ & & & & $\mathbf{X}$ & \\
\hline 17. & Octadecan-1-ol & $112-92-5$ & $\#$ & $\beta$ & & & & \\
\hline 18. & Octadecane & $593-45-3$ & $\#$ & & $\ddagger$ & & & \\
\hline 19. & Pentadecalactone & $106-02-5$ & $\#$ & & & & & \\
\hline 20. & Pentadecane & $629-62-9$ & & $\beta$ & & 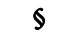 & & \\
\hline 21. & Phenoxybenzene & $101-84-8$ & & $\beta$ & & & & \\
\hline 22. & Tetradecane & $629-59-4$ & & $\beta$ & $\ddagger$ & $\$$ & $\mathrm{X}$ & $\Phi$ \\
\hline 23. & Tridecane & $629-50-5$ & & & & 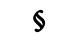 & & \\
\hline 24. & Undecane & $1120-21-4$ & \# & $\beta$ & $\ddagger$ & 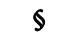 & $\mathrm{X}$ & $\Phi$ \\
\hline
\end{tabular}

CAS Number $=$ Chemical Abstract registry Number. $\#=$ PCPs detected-Summer 2014; $\boldsymbol{\beta}=$ PCPs detected-Summer 2015; $\neq=$ PCPs detected-Fall 2014; $\$=$ PCPs detected-Fall 2015; X = PCPs detected-Winter 2015; $\boldsymbol{\Phi}=$ PCPs detected-Winter 2016. 
perfuming agent were also detected. Another chemical that was found was Pentadecalactone a cream cleanser that is used for antiperspirant and deodorant. Pentadecane and Phenoxybenzene were also detected during the summer of 2014 and 2015. Both of these compounds are perfuming or fragrance agents. The PCPs that were detected in the fall of 2014 and 2015 included 3-Hexanol a perfuming or fragrance agent, and Disiloxane an emollient in skin conditioners. Additionally, the following fragrance agents were detected including Docosane, Heneicosane, Heptadecane, Hexadecane, Hexyl butanoate, Octadecane, Pentadecane, Tetradecane, and Tridecane. Similarly, in the winter of 2015 and 2016 the following PCPs were detected 1-Chlorodecane, an anti-microbial agent; 1-Hexadecanol, an opacifier in shampoos and emollient in skin creams, and 2,6-dimethyloctan-2-ol a perfuming or fragrance agent. Cyclotrisiloxane, Disiloxane, and Isohexyl palmitate which are emollient for both skin and hair conditioner were also detected. The following perfuming agents Heneicosane, Heptadecane, Hexadecane, and Methyl heptanoate were detected. The compounds Methyl Palmitate an intensive skin care lotion and Tetradecane a fragrance agent were also found during the winter of 2015 and 2016. However, Undecane an emollient in skin conditioners was detected throughout the three seasons.

Collins River data: The personal care products (PCPs) detected in Collins River during the sampling years of 2014, 2015 and 2016 are presented in Table 2. The PCPs included 1-Chlorodecane and 1-Hexadecanol. The former is an antimicrobial agent and was detected during summer of 2015 and winter of 2016. Conversely, 1-Hexadecanol an emollient for skin conditioners, lotions, and skin creams was detected in both the winter of 2015 and 2016. Other chemicals that were detected included 2,6-dimethyloctan-2-ol and 2-methylpropyl butanoate. Both of which are used in perfumes and were found in summer of 2015, and summer of 2014 respectively. The chemical 4-methylpentyl hexadecanoate, an emollient for skin conditioner was detected in the winter of 2015. Some skin and hair conditioners were also identified in Collins River. They include Cedrol, found in summer 2014, Cyclotrisiloxane and Disiloxane found in winter of both 2015 and 2016. Dodecan-1-ol an emollient for skin conditioners, creams, lotions, lipsticks, and face cleanser was found during summer of 2014, fall of 2014, and fall of 2015. Heptadecane, a perfuming or fragrance agent was detected in all the three seasons of 2014, 2015 and 2016. Similarly, Hexadecane another perfuming agent was also found throughout the sampling period except for winter of 2015 and summer of 2015. Hexadecanoic acid and Isohexyl palmitate both of which are emollients for creams, lotions, lipsticks, shampoos, soaps, and skin conditioner were detected in both summer of 2014 and winter of 2015. Methyl pentanoate a fragrance agent was detected in both summer and fall of 2015. Nonanal a stabilizer in hair sprays, shampoos, and creams was found in the summer of 2014 and winter of 2016. Similarly, Octadecan-1-ol a chemical used in antiperspirant sticks was detected in summer of 2014. Octadecane a perfuming agent and skin conditioner was found in the summer of 2014 as well. Octadecan-1-ol was 
Table 2. Personal Care Products, $\mathrm{n}=2$; Collins River: Summer 2014, Fall 2014, Winter 2015, Summer 2015, Fall 2015 and Winter 2016.

\begin{tabular}{|c|c|c|c|c|c|c|c|c|}
\hline \multirow{2}{*}{$\#$} & \multirow{2}{*}{ Chemical Name } & \multirow{2}{*}{$\begin{array}{c}\text { CAS } \\
\text { Number }\end{array}$} & \multicolumn{2}{|c|}{ Summer } & \multicolumn{2}{|c|}{ Fall } & \multicolumn{2}{|c|}{ Winter } \\
\hline & & & 2014 & 2015 & 2014 & 2015 & 2015 & 2016 \\
\hline 1. & 1-Chlorodecane & $1002-69-3$ & & $\beta$ & & & & $\Phi$ \\
\hline 2. & 1-Hexadecanol & $36653-82-4$ & & & & & $\mathrm{X}$ & $\Phi$ \\
\hline 3. & 2,6-dimethyloctan-2-ol & $18479-57-7$ & & $\beta$ & & & & \\
\hline 4. & 2-methylpropyl butanoate & $539-90-2$ & $\#$ & & & & & \\
\hline 5. & 4-methylpentyl hexadecanoate & $55194-91-7$ & & & & & $\mathrm{X}$ & \\
\hline 6. & Cedrol & $77-53-2$ & $\#$ & & & & & \\
\hline 7. & Cyclotrisiloxane & $541-05-9$ & & & & & $\mathrm{X}$ & $\Phi$ \\
\hline 8. & Disiloxane & $107-46-0$ & & & & & $\mathrm{X}$ & $\Phi$ \\
\hline 9. & Dodecan-1-ol & $112-53-8$ & $\#$ & & $\ddagger$ & 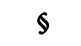 & & \\
\hline 10. & Dodecanal & $112-54-9$ & & $\beta$ & & & & $\Phi$ \\
\hline 11. & Heptadecane & $629-78-7$ & $\#$ & $\beta$ & $\ddagger$ & $\S$ & $\mathrm{X}$ & $\Phi$ \\
\hline 12. & Hexadecane & $544-76-3$ & $\#$ & & $\ddagger$ & $\S$ & & $\Phi$ \\
\hline 13. & Hexadecanoic acid & $57-10-3$ & $\#$ & & & & $\mathrm{X}$ & \\
\hline 14. & Isohexyl palmitate & $55194-91-7$ & $\#$ & & & & $\mathrm{X}$ & \\
\hline 15. & Methyl pentanoate & $624-24-8$ & & $\beta$ & & $\S$ & & \\
\hline 16. & Nonanal & $124-19-6$ & $\#$ & & & & & $\Phi$ \\
\hline 17. & Octadecan-1-ol & $112-92-5$ & $\#$ & $\beta$ & & & & \\
\hline 18. & Octadecane & $593-45-3$ & $\#$ & & & & & \\
\hline 19. & Pentadecane & $629-62-9$ & & $\beta$ & & $\S$ & & $\Phi$ \\
\hline 20. & Tetradecane & $629-59-4$ & & & $\ddagger$ & $\S$ & & $\Phi$ \\
\hline 21. & Tridecane & $629-50-5$ & $\#$ & $\beta$ & & & & \\
\hline 22. & Undecane & $1120-21-4$ & & $\beta$ & $\ddagger$ & & & $\Phi$ \\
\hline
\end{tabular}

CAS Number $=$ Chemical Abstract registry Number; \# = PCPs detected-Summer 2014; $\beta=$ PCPs detected-Summer 2015; $\neq=$ PCPs detected-Fall 2014; $\$=$ PCPs detected-Fall 2015; $\mathbf{X}=$ PCPs detected-Winter 2015; $\boldsymbol{\Phi}=$ PCPs detected-Winter 2016.

also identified in summer of 2015. Furthermore, Pentadecane and Tetradecane both fragrance agents were detected in fall of 2015 and winter of 2016. While the chemical Tridecane, a perfuming agent, was found in summer of 2014 and 2015, the chemical Undecane an emollient for skin conditioning was detected during fall of 2014, summer of 2015, and winter of 2016.

River Temperature: Temperature tends to be the most commonly analyzed water quality parameter because it affects both chemical and biological characteristics of the water. Moreover, every organism exhibits a preferred range or tolerance for temperature. Therefore temperature affects the watershed ecosystem functions. As shown in Figure 6 and Figure 7 both rivers were warmer in the summer months. The temperature values ranged from $3.7^{\circ} \mathrm{C}$ to $26^{\circ} \mathrm{C}$ for 


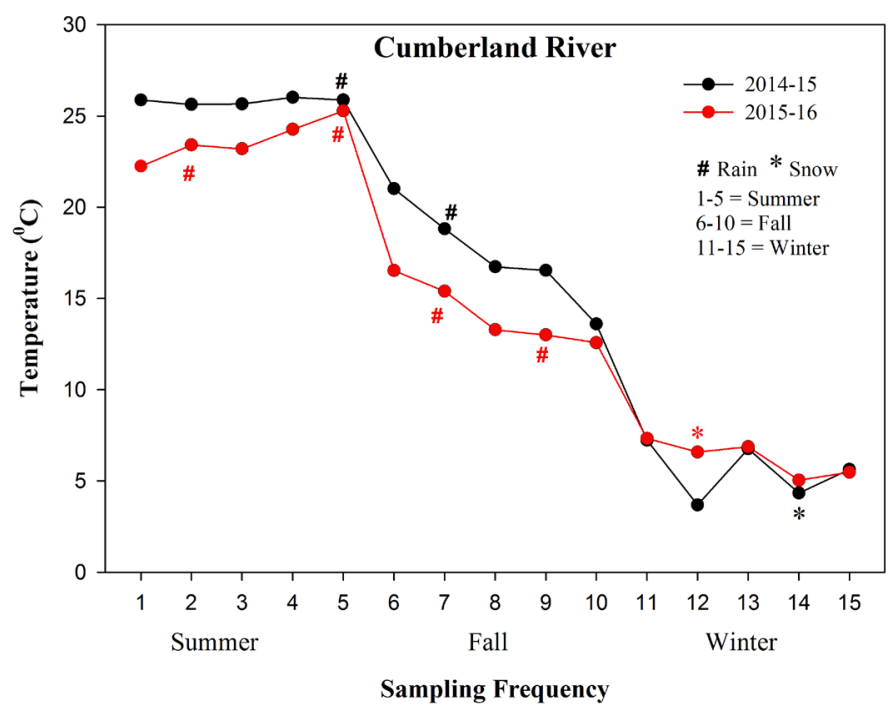

Figure 6. Temperature, $\mathrm{n}=2$; Cumberland River: Summer 2014, Fall 2014, Winter 2015, Summer 2015, Fall 2015 and Winter 2016.

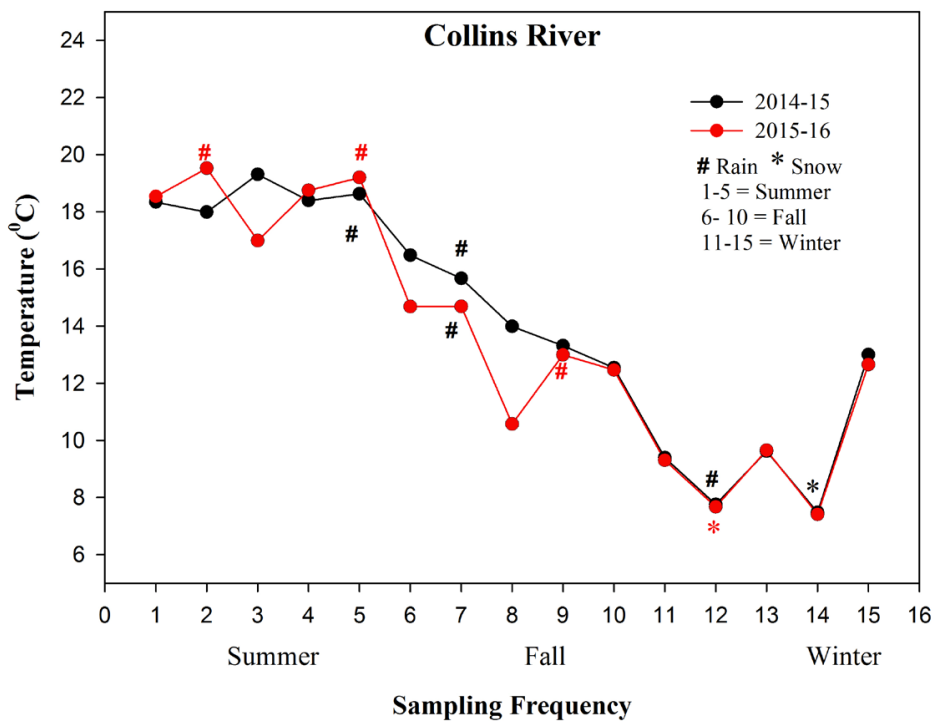

Figure 7. Temperature, $\mathrm{n}=2$; Collins River: Summer 2014, Fall 2014, Winter 2015, Summer 2015, Fall 2015 and Winter 2016.

Cumberland River and $7.4^{\circ} \mathrm{C}$ to $19.3^{\circ} \mathrm{C}$ for Collins River during the sampling period of 2014, 2015 and 2016. As a result Cumberland River located in an urban watershed showed the propensity to be warmer than Collins River which is in a rural watershed. This might be due to the shading effect associated with a rural sub-watershed where there are more trees and shrubs.

River $\mathrm{pH}: \mathrm{pH}$ is a measure of acidity or alkalinity over a range of $0-14$ scale. Water $\mathrm{pH}$ is a valuable indicator of chemical water quality because $\mathrm{pH}$ can influence the availability of chemicals in water. Moreover, $\mathrm{pH}$ also affects solubility and biological availability of nutrients and heavy metals. As a result, it affects the mobility of many pollutants in a water body. 
During the sampling period of 2014, 2015 and 2016, Cumberland River (Figure 8 ) had $\mathrm{pH}$ values that ranged from 6.5 to 8.6 with an average $\mathrm{pH}$ of 7.9. Conversely, the $\mathrm{pH}$ values for Collins River (Figure 9) ranged from 7.2 to 8.9 and had an average $\mathrm{pH}$ value of 7.8. According to United States Geological Survey (USGS) the normal $\mathrm{pH}$ for rivers ranged from $\mathrm{pH} 6$ to 8 . Both rivers that were monitored tend to have $\mathrm{pH}$ in this range.

River Dissolved Oxygen: Dissolved oxygen is very important water quality parameter. It is highly dependent on temperature. The solubility of oxygen decreases with increase in temperature and consequently dissolved oxygen decreases. A minimum of $5 \mathrm{mg} / \mathrm{L}$ of dissolved oxygen is required to support aquatic life; however a reading around $7 \mathrm{mg} / \mathrm{L}$ is ideal [14].

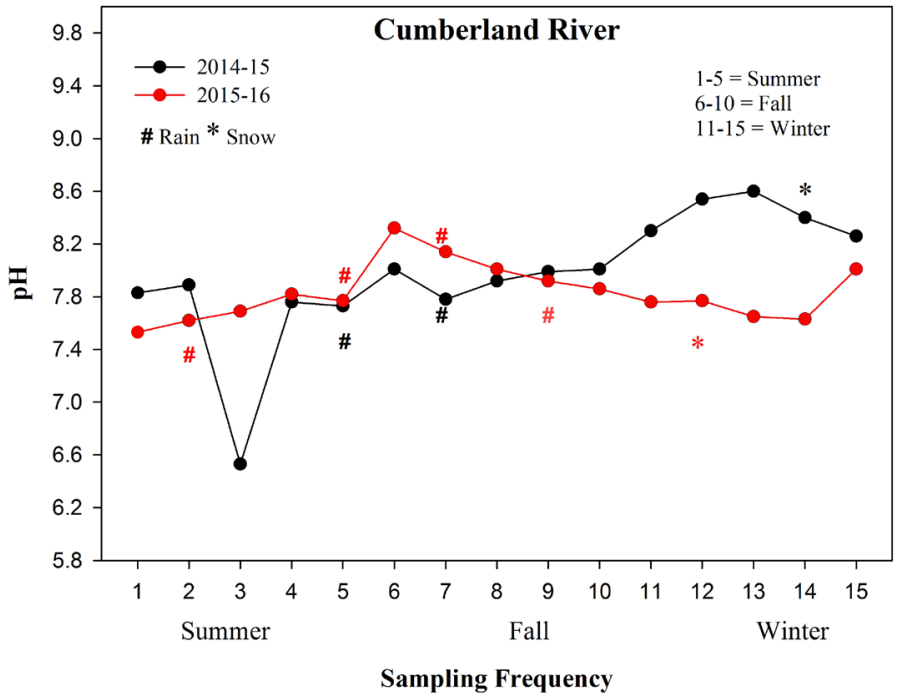

Figure 8. $\mathrm{pH}, \mathrm{n}=2$; Cumberland River: Summer 2014, Fall 2014, Winter 2015, Summer 2015, Fall 2015 and Winter 2016.

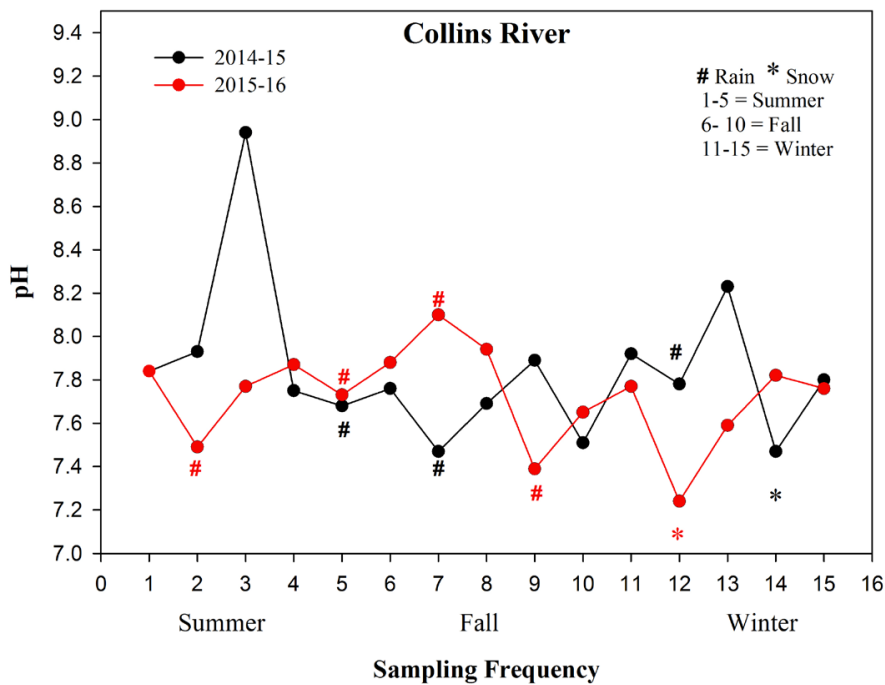

Figure 9. $\mathrm{pH}, \mathrm{n}=2$; Collins River: Summer 2014, Fall 2014, Winter 2015, Summer 2015, Fall 2015 and Winter 2016. 
The dissolved oxygen in both the rivers monitored was higher than $5 \mathrm{mg} / \mathrm{L}$. The dissolved oxygen values for Cumberland River ranged from $6.3 \mathrm{mg} / \mathrm{L}$ to 12.8 $\mathrm{mg} / \mathrm{L}$. In Collins River the values ranged from $7.6 \mathrm{mg} / \mathrm{L}$ to $12.2 \mathrm{mg} / \mathrm{L}$. There was a strong relationship between the dissolved oxygen of the rivers and the temperature of the rivers as indicated in Figure 10 and Figure 11. However the values change significantly from summer to winter.

River Turbidity: United States Environmental Protection Agency (US-EPA) uses turbidity to measure water clarity and as an indicator for sediment load in streams. It is expressed by the amount of light that is scattered by material in the water when light passes through water [15]. Turbidity can be caused by several

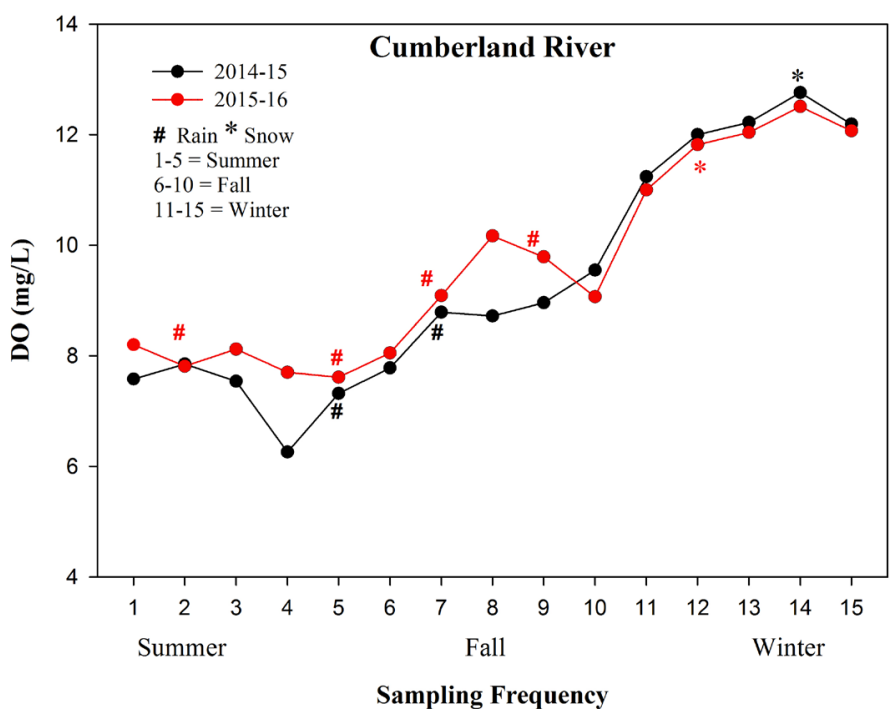

Figure 10. Dissolved Oxygen, $\mathrm{n}=2$; Cumberland River: Summer 2014, Fall 2014, Winter 2015, Summer 2015, Fall 2015 and Winter 2016.

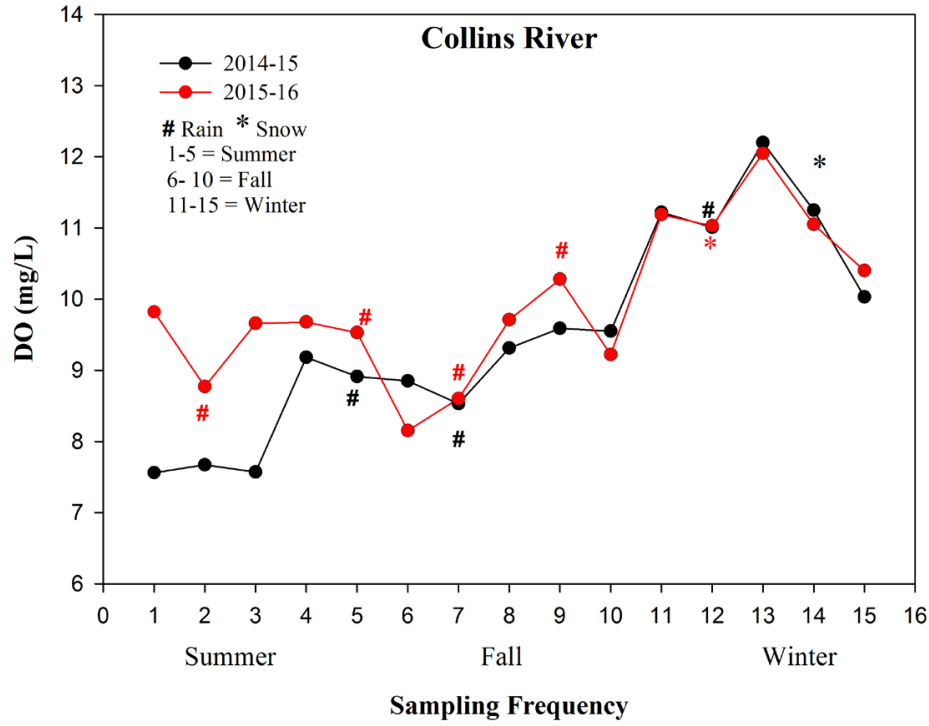

Figure 11. Dissolved Oxygen, $\mathrm{n}=2$; Collins River: Summer 2014, Fall 2014, Winter 2015, Summer 2015, Fall 2015 and Winter 2016. 
ecosystem events such as soil erosion, water discharge during the urban runoff, eroding stream banks, a large number of bottom feeders, and excessive algal growth [16]. Turbidity is measured in nephelometric turbidity units (NTUs).

Turbidity in Collins River ranged from 1.4 to 20 NTUs (Figure 12). These values were similar to those obtained by [17] in creeks in Warren County, Tennessee. On the other hand, the turbidity values for Cumberland River (Figure 13) ranged from 1.6 to 27.2 NTUs.

\section{Conclusion}

Personal care products include a wide variety of chemicals that have different

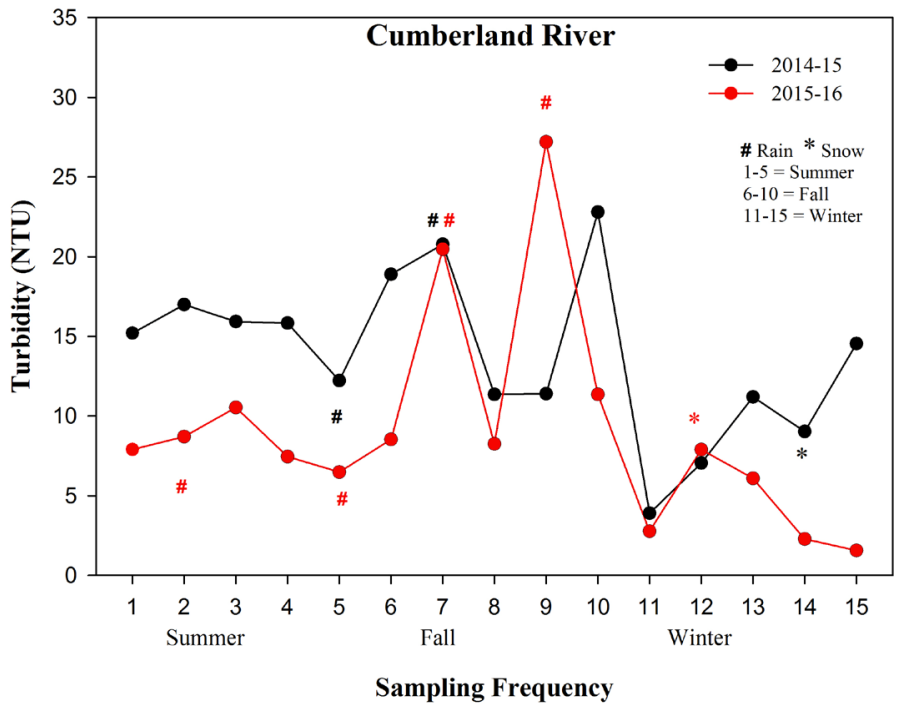

Figure 12. Turbidity, $\mathrm{n}=2$; Cumberland River: Summer 2014, Fall 2014, Winter 2015, Summer 2015, Fall 2015 and Winter 2016.

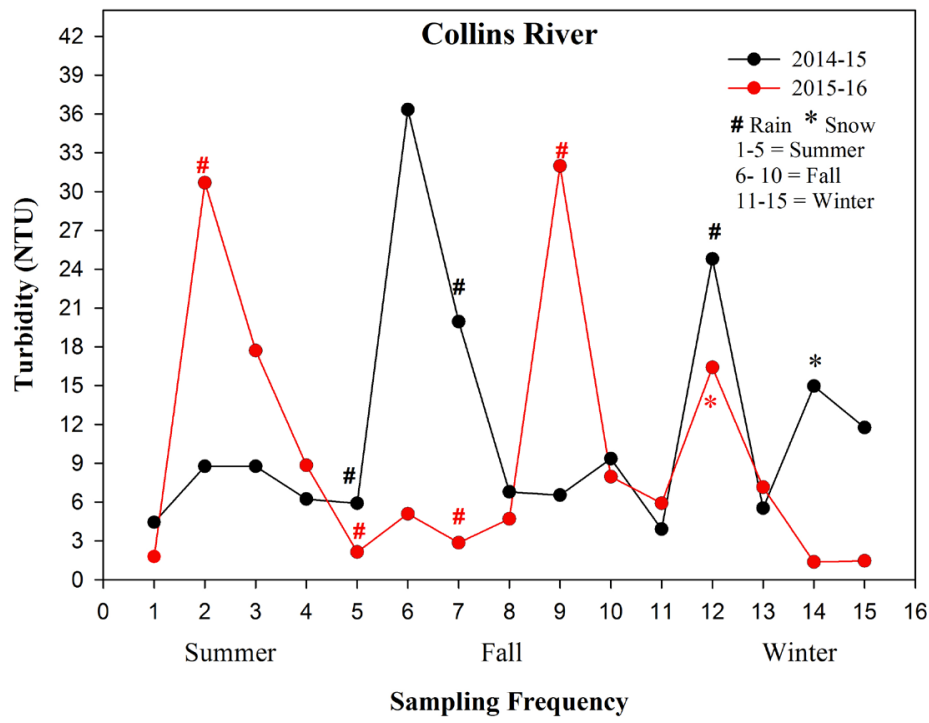

Figure 13. Turbidity, $\mathrm{n}=2$; Collins River: Summer 2014, Fall 2014, Winter 2015, Summer 2015, Fall 2015 and Winter 2016. 
mode of action and intended uses. Due to this complexity, it is challenging to understand the effect of these chemicals on non-target organisms in water ecosystems especially in surface water. Among personal care products, detergents and soaps are considered to be the most prevalent pollutants partly due to the presence of surfactant in their formulations. Based on our studies, the most detected class of personal care products in both Cumberland and Collins River was fragrances. As expected, it could be due to their diverse use in several categories of cosmetics formulations. Additionally, the availability and affordability of these chemicals could be another reason for their widespread applications. All in all, the personal care products detected in surface water during this study included emollients, anti-microbial agents, skin conditioning agents, surfactants from soaps, shampoos, detergents, hair sprays, antiperspirants and deodorants, and moisturizers. As expected, we found more perfuming or fragrance agents in surface water drained by urban watershed. On the other hand, more active ingredients associated with skin conditioners or lotions were detected in surface water of rural watershed. These findings can be explained by land use and lifestyle in both watersheds. While the scope of this study did not include delineating the actual concentrations of these chemicals in water, the detected concentrations were in the $\mathrm{ng} / \mathrm{L}$ range. At this concentration range, the chemicals pose minimal to no physical damage to aquatic organisms. However, they may have the potential of causing behavioral issues. This has been corroborated by some studies [18] [19] [20] [21] [22]. Another concern with the presence of these chemicals in surface water is the possibility of contaminating source water used for drinking water. Subsequently, there is dire need for more comprehensive studies to examine the effect of these chemicals on our water ecosystem.

\section{Acknowledgements}

This study was funded by USDA-Evans Allen program and the College of Agriculture at Tennessee State University. We would like to acknowledge Dr. Sayed M. Hassan and his team at Environmental Analysis Laboratory at the University of Georgia, Athens, GA for providing their assistance in the analysis of water samples.

\section{References}

[1] Richardson, S.D. (2009) Water Analysis: Emerging Contaminants and Current Issues. Analytical Chemistry, 81, 4645-4677. https://doi.org/10.1021/ac9008012

[2] Peng, X., Xiong, S., Ou, W., Wang, Z., Tan, J., Jin, J., Tang, C., Liu, J. and Fan, Y. (2017) Persistence, Temporal and Spatial Profiles of Ultraviolet Absorbents and Phenolic Personal Care Products in Riverine and Estuarine Sediments of the Pearl River Catchment, China. Journal of Hazardous Materials, 323, 139-146. https://doi.org/10.1016/j.jhazmat.2016.05.020

[3] Gago-Ferrero, P., Diaz-Cruz, M.S. and Barcelo, D. (2015) UV Filters Bioaccumulation in Fish from Iberian River Basins. Science of the Total Environment, 518-519, 518-525. https://doi.org/10.1016/j.scitotenv.2015.03.026

[4] Gautam, P., Carsella, J.S. and Kinney, C.A. (2014) Presence and Transport of the 
Antimicrobials Triclocarban and Triclosan in a Wastewater-Dominated Stream and Freshwater Environment. Water Research, 48, 247-256.

https://doi.org/10.1016/j.watres.2013.09.032

[5] Gorga, M., Insa, S., Petrovic, M. and Barcelo, D. (2015) Occurrence and Spatial Distribution of EDCs and Related Compounds in Waters and Sediments of Iberian Rivers. Science of the Total Environment, 503-504, 69-86. https://doi.org/10.1016/j.scitotenv.2014.06.037

[6] Haman, C., Dauchy, X., Rosin, C. and Munoz, J-F. (2015) Occurrence, Fate and Behavior of Parabens in Aquatic Environments: A Review. Water Research, 68, 1-11. https://doi.org/10.1016/j.watres.2014.09.030

[7] Rodriguez, A.S., Sanz, M.R. and Rodriguez, J.R.B. (2015) Occurrence of Eight UV Filters in Beaches of Gran Canaria (Canary Islands). An Approach to Environmental Risk Assessment. Chemosphere, 131, 85-90. https://doi.org/10.1016/j.chemosphere.2015.02.054

[8] Wang, W. and Kannan, K. (2016) Fate of Parabens and Their Metabolites in Two Wastewater Treatment Plants in New York State, United States. Environmental Science and Technology, 50, 1174-1181. https://doi.org/10.1021/acs.est.5b05516

[9] Daughton, C.G. and Ternes, T.A. (1999) Pharmaceuticals and Personal Care Products in the Environment: Agents of Subtle Change? Environmental Health Perspectives, 107, 907-938. https://doi.org/10.1289/ehp.99107s6907

[10] Monteiro, S.C. and Boxall, A.B.A. (2009) Factors Affecting the Degradation of Pharmaceuticals in Agricultural Soils. Environmental Toxicology and Chemistry, 28, 2546-2554. https://doi.org/10.1897/08-657.1

[11] Buser, H.R., Balmer, M.E., Schmid, P. and Kohler, M. (2006) Occurrence of UV Filters 4-Methylbenzylidene Camphor and Octocrylene in Fish from Various Swiss Rivers with Inputs from Wastewater Treatment Plants. Environmental Science and Technology, 40, 1427-1431. https://doi.org/10.1021/es052088s

[12] Fent, K., Zenker, A. and Rapp, M. (2010) Widespread Occurrence of Estrogenic UV-Filters in Aquatic Ecosystems in Switzerland. Environmental Pollution, 158, 1817-1824. https://doi.org/10.1016/j.envpol.2009.11.005

[13] Nakata, H., Murata, S. and Filatreau, J. (2009) Occurrence and Concentration of Benzotriazole UV Stabilizers in Marine Organisms and Sediments from the Ariake Sea, Japan. Environmental Science and Technology, 43, 6920-6926.

[14] University Wisconsin Green Bay. (2005) Dissolved Oxygen. Lower Fox River Watershed Monitoring Program, Green Bay, WI.

https://www.uwgb.edu/watershed/data/chemistry.asp

[15] USGS. (2015) Turbidity-Water Properties, USGS Water Science School. https://water.usgs.gov/edu/turbidity.html

[16] USEPA. (2015) Turbidity. Water: Monitoring and Assessment. USEPA. https://archive.epa.gov/water/archive/web/html/vms55.html

[17] Hovis, S.K. (2013) Temporal Variability of Water Quality Parameters in Two Creeks of the Collins River Sub-Watershed Dominated by Nursery Crop Production. Master's Thesis, Tennessee State University, Tennessee.

[18] Veldhoen, N., Skirrow, R.C., Osachoff, H., Wigmore, H., Clapson, D.J., Gunderson, M.P., Aggelen, G.V. and Helbing, C.C. (2006) The Bacterial Agent Triclosan Modulates Thyroid Hormone-Associated Gene Expression and Disrupts Postembryonic Anuran Development. Aquatic Toxicology, 80, 217-227. https://doi.org/10.1016/j.aquatox.2006.08.010

[19] Brausch, J.M. and Rand, G.M. (2011) A Review of Personal Care Products in the 
Aquatic Environment: Environmental Concentrations and Toxicity. Chemosphere, 82, 1518-1532. https://doi.org/10.1016/j.chemosphere.2010.11.018

[20] Ramaswamy, B.R., Shanmugam, G., Velu, G., Rengarajan, B. and Larsson, D.G.J. (2011) GC-MS Analysis and Ecotoxicological Risk Assessment of Triclosan, Carbamazepine and Parabens in Indian Rivers. Journal of Hazardous Materials, 186, 1586-1593. https://doi.org/10.1016/j.jhazmat.2010.12.037

[21] Ahmed, M.B., Zhou, J.L., Ngo, H.H., Guo, W., Thomaidis, N.S. and Xu. J. (2017) Progress in the Biological and Chemical Treatment Technologies for Emerging Contaminant Removal from Wastewater: A Critical Review. Journal of Hazardous Materials, 323, 274-298. https://doi.org/10.1016/j.jhazmat.2016.04.045

[22] Bartrons, M. and Penuelas, J. (2017) Pharmaceuticals and Personal Care Products in Plants. Trends in Plant Science, 22, 194-203.

https://doi.org/10.1016/j.tplants.2016.12.010 